\title{
Higher Education Scholarship: Gate To Develop Educational Human Resource Quality
}

\author{
Rusi Rusmiati Aliyyah ${ }^{1, a^{\star}}$, Unifah Rosyidi ${ }^{1, b}$, and Rugaiyah ${ }^{1, c}$ \\ ${ }^{1}$ Educational Management, Post Graduate Program, Universitas Negeri Jakarta, Indonesia \\ a rusi.rusmiati@unida.ac.id; b unifahrosyidi@unj.ac.id; c rugaiyah@unj.ac.id \\ ${ }^{*}$ Corresponding Author \\ Whatsapp Number [ 08176395090]
}

How to Cite: Aliyyah, R.,R Rosyidi, U \& Rugaiyah, R. (2019). Higher Education Scholarship: Gate To Develop Educational Human Resource Quality.. International Journal for Educational and Vocational Studies, 1(4), 349-358

\section{ARTICLE HISTORY}

Received: 12 June 2019

Revised: 10 July 2019

Accepted: 3 August 2019

KEYWORDS

\section{Scholarship;}

Poor people;

Indonesia;

Quality education;

\section{ABSTRACT}

Bidik Misi "(BM) is an extraordinary scholarship provided by the Government of Indonesia with two criteria main: economic needs and academic performance, and added a test Islamic Education at private universities. Since its introduction in 2010, the number of candidates has increased every year, causing difficulties in choosing the most qualified candidates. This study aims to find the effectiveness of the recruitment of participants in scholarship programs for the poor and how to develop the quality of educational resources in Indonesia. Although they have requirements that are not the same as regular students in participating in the admission process at universities, this study shows that private universities can develop the quality of human resources through the BM program.

This is an open access article under the CC-BY-SA license.

\section{INTRODUCTION}

Education is the right of every citizen, including those from the economically poor family. In facts, not every citizen can access higher education as, for some poor people, is unaffordable. Assessing education is human rights. Human rights education covers activities and practices to develop knowledge, skill, understanding, attitude, and awareness which are necessary for promoting, preserving, and advocating fundamental rights (Doganay \& Ozturk, 2017). Human rights include access to education for students who have poor or needy economic ability (Benavot, 2016a). Education can create competent and qualified human resources, which finally result in the increasing of social development index in which one of the indicators is the level of education of the citizen. It means that the higher education the people within a country is, the higher human development index of the state will be. Education has a significant impact on increasing the human development index of one country.

In Indonesia, access to higher education seems to be controlled by those with the ability of finance as the cost of higher education is very expensive. According to the data of the Ministry of Research, Technology, and Higher Education of the Republic of Indonesia, only about $30 \%$ of high school graduates in Indonesia continue to college (Ristekdikti, 2015). This is caused by higher poverty in Indonesia. The latest data shows that 27,7 million people are still under poverty lines (Biro Pusat Statistik, 2016).

The government, through the special scholarship called BM tries to accommodate those with financial barriers. BM scholarship is the government programs initiated to open broader access for everyone as the concept of education for all. The target of the program itself is to increase the access and opportunities to higher education for outstanding economically low-income family students.

The solution to the problem is by providing equal access to all people, especially those from an economically low-income family. The government, the local government, and universities must serve those from a financially low-income family so that they can access higher education (Sekneg, 2012). The fund of BM is also budgeted in the National budget (Kemendikbud, 2014b). The 
concept of providing scholarship was also introduced in the Malaysian government as it covers the indigenous people of Malay to access higher education (Younus, Farooq, Tabassum, \& Scholar, 2017). The same case also happens in the Tennesse United States, which also provide a scholarship for those from a low-income family to high-quality university (Villalobos, Treviño, Wyman, \& Scheele, 2017). The overall target of that scholarship is to reduce poverty and unemployment. This research is trying to find how the BM scholarship program can help students develop their Intellectual Competency (IQ), Social Competency (SQ), Adversity Quotients (AQ) and Spiritual Competency (SQ). In the Intelligent Quotient (IQ), the research is trying to find how well the students achieve the academic performance during the process of the study indicated with the achievement of Grade Point Academic od each semester. The social competency is shown as a result of the students participated in the campus activities, the spiritual skills are demonstrated in the ability to recite Holy Koran, and the last is the Adversity Quotients shown by the strength of the students in finishing the study on time as standardized by government and university.

This research tries to find out how the BM scholarship program can develop the quality of Human Resources Education at UNIDA. As a private university through the BM scholarship program by seeing the realization of candidates for scholarship program $\mathrm{BM}$ at the $\mathrm{BM}$ selection have ability academic, come from economically disadvantaged families (poor), and have knowledge of Islamic Religious Education (PAI) that is qualified with the Qur'an memorization test. Research also examines how the realization of human resources includes program managers and lecturers as a foundation in implementing the learning process in higher education.

\section{Poverty}

The Centers for Disease Control and Prevention (2014) define poverty as "when a person or group of people lack human needs because they cannot afford them. Human needs include clean water, nutrition, health care, education, clothing, and shelter" (Hitchcock et al., 2018). In the USA itself, the poverty according to federal guidelines is a family of four with an annual income of $\$ 24.600$ or less is classified as living in poverty (Williams $\&$ Nourie-manuele, 2018). In short, poverty is the inability of a person or group of people to meet basic needs (Williams \& Nourie-manuele, 2018; Hitchcock et al., 2018; Hannum et al., 2017).

\section{Human Development Index}

The Human Development Index (HDI) is an indicator that measures individuals' welfare through three dimensions: health, education, and income (Caroline \& Miranda, 2014; Chaaban, Irani, \& Khoury, 2015; Lourenc, 2017). The Human Development Index (HDI) is a summary measure of achievements in critical dimensions of human development (UNDP, 2016). Despite the previous description on the human development index, there are three social dimensions compose it: Long and Healthy Life (LHL), Access to Knowledge (ATK) and the Decent Standard of Living (DSL) (Lourenc, 2017). The essentials for human development are thus the ability to live a long, healthy life, to acquire knowledge, to access the resources necessary to a decent standard of living and to take part in the life of the community (Bilbao-ubillos, 2013).

Some various definitions of human development index as mentioned by previous researchers but seen as the concept of UNDP in measuring the country well being Human development index, even though there are some critics on how to measure and the lack of data, is still the only comprehensive measurement on how well a country serves its citizens. There are three keywords in the context of human development index, namely health care, education, and income (Caroline \& Miranda, 2014; Chaaban et al., 2015; UNDP, 2016). The human development index has now become more comprehensive as the indicators vary by the time

\section{Scholarship in Higher Education}

Scholarship programs for higher education attract a substantial body of funding each year from national governments, supranational agencies, large charitable foundations, higher education institutions, and many smaller organizations (Mawer, 2017). In some countries, scholarship in higher education is often framed by strategic management and organization theories (Mwangi, 2018). While the "public scholarship movement" (Mathews, 2005) has spurred deeper and broader exploration and practice of engaged scholarship in higher education (Franz, 2016). It can be concluded that scholarship for higher education is 
one of the instruments to provide access to those from low incomes family students. The scholarship can be fully funded by either the government using state budget or through a partnership with industries in which they can recruit the recipients to work within a period in the company providing the scholarship. The scholarship disbursed by the government will not run smoothly without cooperation and partnership with the higher education institutions as now higher education institutions have increasingly become actors in these international development partnerships (Mwangi, 2018). In 1998, the World Conference on Higher Education (WCHE), organized by UNESCO, put forth a call for the higher education sector to become more engaged in international development agendas, particularly sustainable sociocultural and economic development (Mwangi, 2018). The partnership the government can spread the awareness to the higher education institutions through scholarship.

\section{Education For All}

Education for all has long been reviewed and discussed as it was assumed that the poverty and unemployment in every country are mostly caused by lower education level and the access to higher education is very limited especially for those from low-income family students. Global Monitoring Report initiated by the UNESCO, resulting in 5 goals that would help the implementation of education for all. They are expanding early childhood care and education; achieving universal primary education; ensuring equal access to learning and life skills for youth and adults; challenging the government to reduce adult illiteracy; and focusing attention on gender parity and equality (Benavot, 2016b). While Guo defines the Education For All as a process of lifelong learning which is a holistic, visionary, normative and value-laden concept in the same way as are ideas about democracy or equality (Guo, 2014). Life long learning is the integration of learning and living, covering learning activities for people of all ages through a variety of modalities. Life long learning ultimate goals are to ensure the optimum educational access rates for improving the quality of human resources (Madani, 2019). Education has been an excellent tool to bring about advancement and development in the nation indeed as proven by advanced nations of the world (Irabor, 2018). Education for all is like an investment from a country to improve the quality of human resources, which finally results in the development of productivities. If the productivity of human resource within a country, it will be much easier to design the growth as the investors from other countries will come. Productivity is talking about the effectiveness of human resources in building a nation. A higher level of education can only produce productivity. Many believe that education is an essential tool for the social and economic growth of a country (Villalobos, Treviño, Wyman, \& Scheele, 2017; Madani, 2019).

\section{Bidikmisi Scholarship}

Higher education, in some countries, needs a lot of money to invest, and this condition puts the low-income family to stop expecting to continue their education in universities. In the United States itself, students from low-income family do not set a college as an option. However, not all high school students always see college as an option. For low-income students, the cost can be a determining factor. If funds are insufficient, or students believe that there are no funds to access, then students are less likely to apply for and attend college" (Tierney, Sallee, \& Venegas, 2016). In Indonesia, itself with the numbers of poverty are still high, numbered 27,7 million people (Biro Pusat Statistik, 2016). The data above confirms what happens in Indonesia which states that only According to the data of the Ministry of Research, Technology, and Higher Education of the Republic of Indonesia, only about $30 \%$ of high school graduates in Indonesia continue to college (Ristekdikti, 2015). The government creates program, namely Bidikmisi scholarship in which one of the targets is to provide access and opportunity to study at higher education for the outstanding students coming from low-income families. The BM scholarship program is based on the regulation as the way to help the poor exceptional students continue their higher education (Kemendikbud, 2014; Direktorat Jenderal Pembelajaran dan Kemahasiswaan Kementerian Riset Teknologi dan Pendidikan Tinggi., 2016).

\section{METHODS}

This research used qualitative with the case study method. Qualitative research with case study method was used to analyze and answer problems and also gain a 
valuable result (Creswell, 2012; Miles B Matthew, Hubbermean A Michael, Saldana, 2014). Case study research process is defined by a systematic series of steps designed to provide a careful analysis of the case (Hancock, Dawson R and Alozzine, 2006). The data collection was carried out through interviews, questionnaires, documentation, and field notes. Data validity was done through 4 steps, namely credibility, transferability, dependability, and conformability (Miles, Mathew B, Hubermen, Michael, Saldana, 2014). Reliability is a real value. Do the findings of the study make sense? Are they credible to the people studied, members of the research community, and others? Transferability - Do the conclusions of a survey have any more considerable effect? Are they transferable to other contexts? Do they fit with what we already know? How far can findings be generalized? Is dependability the process of the study consistent and reasonably stable over time and across researchers and methods? (Miles, Mathew B, Hubermen, Michael, Saldana, 2014). Data analysis consists of data reduction, display, and verification (Huberman, 1992).

The research was conducted at Djuanda University, one of the Universities in Indonesia with the second highest number of BM scholarship recipients in 2016 numbering 147 students. The students of BM recipients spread out at six faculties, namely agriculture faculty, Faculty of Teacher Training and Education, halal food faculty, Economy Faculty, and Law and Politics Faculty.

\subsection{Participants Bidikmisi}

In addition to administrative requirements, UNIDA has a method of recruiting prospective participants through a selection mechanism consisting of a) Having abilities academic (top 10 in high school), b) Originating from economically disadvantaged families ( poor), c) Passed the Test of Education Islamic.

\subsubsection{Academic Ranking of Participants}

The Academic Ranking Program is indicated by academic achievement achieved by prospective Bidimisi scholarship program participants when they are studying in school High. Based on the results of observations and studies of BM program selection at UNIDA Bogor researchers obtained data as table 4.31 Table 4.31 Academic Ranking of BM Scholarship Program Participants Source: Djuanda University New Student Promotion and Admission Bureau (BPPMB) Table 4.31 states that academic ranks of BM scholarship program participants from the 2013 to 2017 academic year has a 100\% educational qualification according to the design specified in the UNIDA BM scholarship program, namely all program participants have good academic abilities and can be proven by the value or ranking of learning achievement from the report cards collected at registration selection of BM scholarship programs at UNIDA. Characteristics of the academic rankings of participants in the UNIDA BM scholarship program are depicted in table 1.

\section{RESULTS AND DISCUSSIONS}

Table 1. Academic Ranking of Bidikmisi Scholarship Program Participants

\begin{tabular}{|c|c|c|c|c|c|c|c|c|c|c|c|c|}
\hline \multirow[t]{3}{*}{ Ranking } & & \multicolumn{9}{|c|}{ School Year } & \multicolumn{2}{|l|}{ Total } \\
\hline & \multicolumn{2}{|c|}{$2013 / 2014$} & \multicolumn{2}{|c|}{$2014 / 2015$} & \multicolumn{2}{|c|}{$2015 / 2016$} & \multicolumn{2}{|c|}{$2016 / 2017$} & \multicolumn{2}{|c|}{$2017 / 2018$} & \multirow{2}{*}{$\begin{array}{l}\text { Total } \\
\text { Total }\end{array}$} & \multirow{2}{*}{$\frac{(\%)}{(\%)}$} \\
\hline & Total & $(\%)$ & Total & $(\%)$ & Total & $(\%)$ & Total & $(\%)$ & Total & $(\%)$ & & \\
\hline $1 \mathrm{~s} / \mathrm{d} 3$ & 8 & 16.3 & 3 & 12 & 8 & 24.3 & 7 & 17.5 & 4 & 16 & 30 & 17.4 \\
\hline $4 \mathrm{~s} / \mathrm{d} 6$ & 12 & 24.5 & 8 & 32 & 11 & 33.3 & 23 & 57.5 & 10 & 40 & 64 & 37.2 \\
\hline $7 \mathrm{~s} / \mathrm{d} 10$ & 29 & 59.2 & 14 & 56 & 14 & 42.4 & 10 & 25 & 11 & 44 & 78 & 45.4 \\
\hline Total & 49 & 100 & 25 & 100 & 33 & 100 & 40 & 100 & 25 & 100 & 172 & 100 \\
\hline
\end{tabular}

Source: Djuanda University New Student Promotion and Admission Bureau (BPPMB)

Table 3.1 states that academic ranks of $\mathrm{BM}$ scholarship program participants from the 2013 to 2017 academic year has a $100 \%$ academic qualification according to the design specified in the UNIDA BM scholarship program, namely all program participants have good academic abilities and can be proven by the value or ranking of learning achievement from the report cards collected at registration selection of BM scholarship 
programs at UNIDA.

Characteristics of the academic rankings of participants in the UNIDA BM scholarship program are depicted in Figure 1.

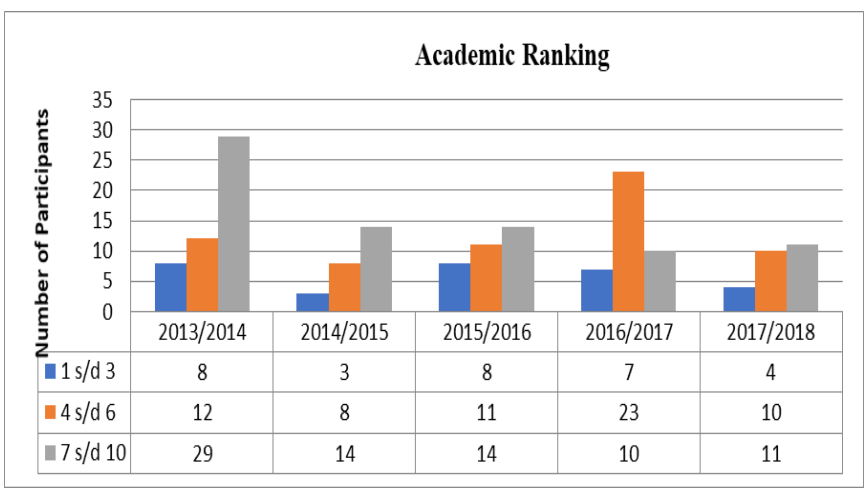

Figure1. Characteristics of Academic Ranking of Participants of the 2013/2014 UNIDA Bidikmisi

Scholarship Program until 2017/2018

Source: Documents of the New Student Promotion and Admission Bureau (BPPMB)

The 100\% BM scholarship program has good academic ability as evidenced by being ranked 1-10 in class X, XI, and XII School report cards High. The academic skills of prospective BM scholarship program participants are essential, considering that BM scholarships are scholarships intended for high graduates school who will continue their studies in college. Learning goals are defined as the mastery of fundamental knowledge and skill precisely defined within individual learning standards. These individual learning standards typically represent an academic skill or a specific piece of content knowledge (Surr,Wendy. Redding, 2017). The result shows how the students have the mastery of the knowledge as shown by the high GPA earned during the study. They also got the competencies which, therefore comprised of a cognitive level (the ability of complex thinking and resolving problems, as well as using the knowledge in a certain área (Peklaj, 2015). This shows the relationship between the result and the theory stating that the cognitive competence is the prior learning that facilitates new learning (Redding, 2015). The cognitive competency can also include an increase in understanding, retention, and application of general concepts; in addition to viewing multiple perspectives and values for global interdependencies; also, interdisciplinary alleviates decision making, thinking critically and creatively, and synthesizing knowledge beyond the discipline. Enhancement of identifying, assessing and transferring significant information to solve new problems (Husni \& Rouadi, 2016).

\subsubsection{Originating from low-income families economically capable (poor)}

The economic background of parents of participants in the BM scholarship program is described according to the type of work and the amount of income of parents per month. The types of work of the program participants' parents consist of 6 types of work, namely: Army Indonesian National/ Indonesian National Police, Private Employees, Entrepreneurs, Civil Servants, Farmers / Fishermen, and other jobs.

Table 2. Job Types of Parents of Bidikmisi Scholarship Program Participants Academic Bidikmisi Year 2013-2017

\begin{tabular}{|c|c|c|c|c|c|c|c|c|c|c|c|c|}
\hline \multirow{3}{*}{ Type of Work } & \multicolumn{10}{|c|}{ School Year } & \multirow{2}{*}{\multicolumn{2}{|c|}{ Total }} \\
\hline & \multicolumn{2}{|c|}{$2013 / 2104$} & \multicolumn{2}{|c|}{$2014 / 2015$} & \multicolumn{2}{|c|}{$2015 / 2016$} & \multicolumn{2}{|c|}{$2016 / 2017$} & \multicolumn{2}{|c|}{$2017 / 2018$} & & \\
\hline & Total & $(\%)$ & Total & $(\%)$ & Total & $(\%)$ & Total & $(\%)$ & Total & $(\%)$ & Total & $(\%)$ \\
\hline TNI/POLRI & 0 & 0 & 0 & 0 & 0 & 0 & 0 & 0 & 0 & 0 & 0 & 0 \\
\hline Private employees & 6 & 12.2 & 4 & 16 & 6 & 18.2 & 8 & 20 & 4 & 16 & 28 & 16.3 \\
\hline Entrepreneur & 12 & 24.5 & 7 & 28 & 9 & 27.3 & 9 & 22.5 & 3 & 12 & 40 & 23.2 \\
\hline Civil servants & 0 & 0 & 0 & 0 & 0 & 0 & 0 & 0 & 0 & 0 & 0 & 0 \\
\hline Farmers / Fishermen & 26 & 53.1 & 11 & 44 & 16 & 48.5 & 19 & 47.5 & 15 & 60 & 87 & 50.6 \\
\hline Others & 5 & 10.2 & 3 & 12 & 2 & 6 & 4 & 10 & 3 & 12 & 17 & 9.9 \\
\hline Total & 49 & 100 & 25 & 100 & 33 & 100 & 40 & 100 & 25 & 100 & 172 & 100 \\
\hline
\end{tabular}

Sources: Observations, Interviews, and Documents of the New Student Admission and Promotion Bureau (BPPMB) of Djuanda University

Based on table 3.2, it is illustrated that the average parents of program participants scholarship UNIDA are farmers/fishermen with a percentage of $50.6 \%$ while $9.9 \%$ of the work of parents of program participants is erratic or odd, which sometimes gets a job and sometimes does not 
get a job.

Distribution of types of work for parents of program participants can be seen in graph 3.2

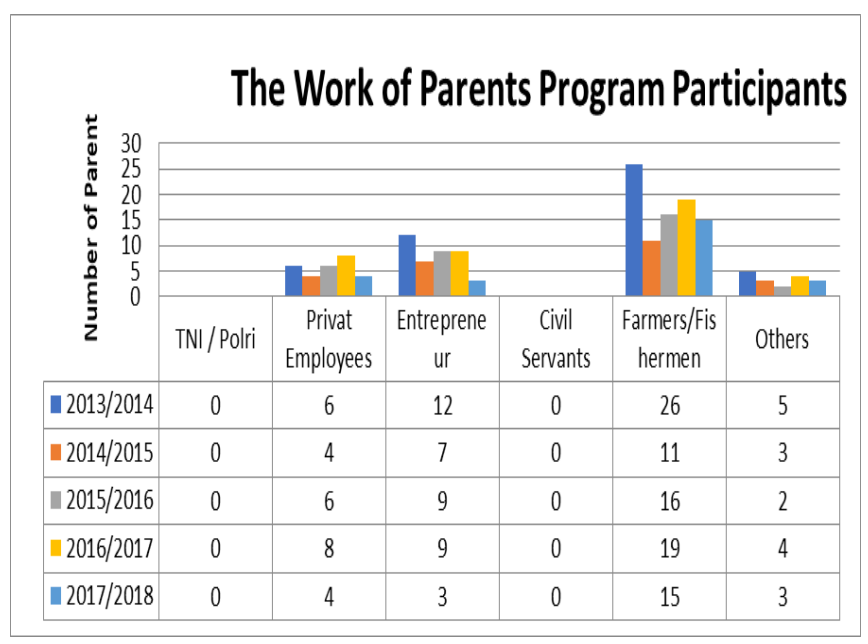

Figure 2. Employment Types of Parents Participants in the 2013-2017 BM Scholarship Program

Source: Observation, Interviews, and Documents of Djuanda University New Student Promotion and Admission Bureau (BPPMB).

Table 3. Parent Income (Combined) Participants in the 2013-2017 BM Scholarship Program

\begin{tabular}{|c|c|c|c|c|c|c|c|c|c|c|c|c|}
\hline \multirow{3}{*}{ Monthly Income } & \multicolumn{10}{|c|}{ Academic year } & \multirow{2}{*}{\multicolumn{2}{|c|}{ Total }} \\
\hline & \multicolumn{2}{|l|}{$2013 / 2014$} & \multicolumn{2}{|c|}{$2014 / 2015$} & \multicolumn{2}{|c|}{$2015 / 2016$} & \multicolumn{2}{|c|}{$2016 / 2017$} & \multicolumn{2}{|c|}{$2017 / 2018$} & & \\
\hline & Total & $(\%)$ & Total & $(\%)$ & Total & $(\%)$ & Total & $(\%)$ & Total & $(\%)$ & Total & $(\%)$ \\
\hline$<500.000$ & 5 & 10.2 & 2 & 8 & 7 & 21.2 & 3 & 7.5 & 4 & 16 & 21 & 12.2 \\
\hline $500.00-1.000 .000$ & 19 & 38.8 & 9 & 36 & 12 & 36.4 & 17 & 42.5 & 7 & 28 & 64 & 37.2 \\
\hline $1.100 .000-2.000 .000$ & 22 & 44.9 & 11 & 44 & 9 & 27.3 & 14 & 35 & 9 & 36 & 65 & 37.8 \\
\hline $2.100 .000-3.000 .000$ & 3 & 6.1 & 3 & 12 & 5 & 15.1 & 6 & 15 & 5 & 20 & 22 & 12.8 \\
\hline $3.100 .000-4.000 .000$ & 0 & 0 & 0 & 0 & 0 & 0 & 0 & 0 & 0 & 0 & 0 & 0 \\
\hline Total & 49 & 100 & 25 & 100 & 33 & 100 & 40 & 100 & 25 & 100 & 172 & 100 \\
\hline
\end{tabular}

Source: Observation, Interviews and Documents UNIDA New Student Promotion and Acceptance Bureau

Table 3 illustrates that the average income of parents (combined husband and wife) of BM scholarship program participants in the range of 1,100,000-2,000,000 whereas $12.2 \%$ of parents of program participants are in the field of less than Rp.500,000. The results of observations conducted by researchers on scholarship program participants offer the 2017/2018 academic year to get participants with a monthly income of only Rp. 300,000 where the wife does, and the husband works irregularly or oddly. So that the income monthly uncertain.

The graph of parents' income (combined husband and wife) of participants in the scholarship program is illustrated in Figure 3.
Furthermore, parents' income (joint)scholarship program participants are bidikmisicategorized into 5 (five) groups consisting of: (a) less than 500,000, (2) 500,000-1,000,000,(3)1,100,000-2,000,000,(4) ,100,000-3,000, 000, (5) $3,100,000-4,000,000$.

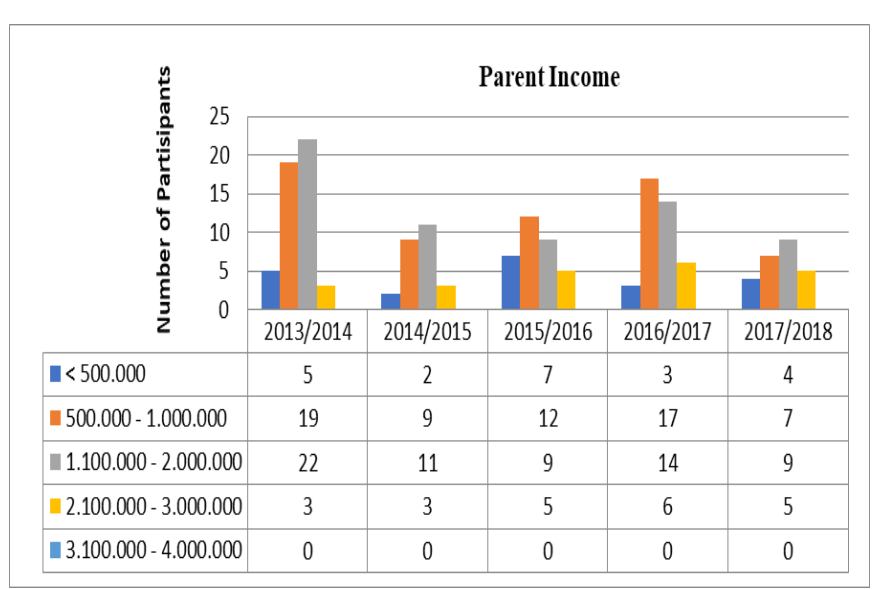

Figure 3. Parent Income (Combined Husband and Wife) Participants in the 2013-2017 Academic Year BM Scholarship Program

Source: Observation, Interviews, and Documents of UNIDA New Student Promotion and Admissions Bureau 
All students who are candidates for the program are declared as recipients of BM scholarships at UNIDA the 2013-2017 academic year were students from economics low or poor. the average income of people ranges from $1,100,000-2,000,000$. This is in accordance with the background and the purpose of giving BM scholarships to students who have good academic abilities but who come from disadvantaged families. Poverty is typically measured by comparing resources to needs, and families or individuals are considered poor if they fall below a threshold (Hannum et al., 2017). World bank categorizes poverty as the individual who spends less than $\$ 1.90$ per individual per day (Bank, 2017). Efforts to reduce poverty in developing countries and transitions have witnessed anti-poverty and massive development projects in the past few decades (Baffoe, 2019). In the United States alone, the number of unemployed and poverty "according to the latest data from the Bureau of Labor Statistics (2010, the unemployment rate in the United States is $10 \%$. Currently, $13.2 \%$ of citizens live below the poverty level (up from $12.5 \%$ in 2007 ) with children accounts for $19 \%$ of this data (Mundy, Leko, \& Mundy, 2017). The result shows that the social competency was demonstrated in the students' participation in campus activities, which can provide them with experience in life skills. The strengthening of social differentiation, the emergence of the "rich" and "poor." By way of consolidation of these relations in society, a financial situation becomes an influential factor in determining the level of aspirations, educational and professional intentions, life strategies of young people (Shaposhnykova \& Shaposhnykov, 2018). Compared to the theory, the students of the BM recipients are mostly able to interact and adapt in different situations, which can lead them to the success of their study.

\subsubsection{Islamic Education Ability (PAI) for Muslim believers}

The ability to master and pass BM selection tests becomes the requirement main for prospective students to get a Decision Letter for the determination of recipients BM scholarship from UNIDA Chancellor. Among the mastery of skills that must be possessed by the program, participants are the PAI test for Muslims. The test PAI consists of 40 questions with multiple choice answers.
This material was given to participants to measure the concept of the religious abilities of program participants. During the test, program participants will be interviewed about memorizing the Quranic verses by the Bureau of the Institute for the Study and Development of Tawhid (LP2T). Assessment aspects in remembering interviews are knowing the total memorization that the program participants have, and knowing the ability of the Qur'an through tahsin, tahfidz, and morality. The total value memorization will be a quality letter with recommended recommendations and not recommended. Based on objective conditions, all (100\%) participants who asset selection the BM scholarship program test had excellent PAI skills.

All program participants who are accepted as BM students have graduated and have good Islamic Education skills through test results and can memorize the Qur'an at least 1 Juz. The spiritual competency in the ability to recite Holy Koran was one of the breakthroughs in balancing between Intelligent Quotient (IQ), Spiritual Intelligence (SQ) and Emotional Intelligent (EQ). This competency itself was only for those entering Djuanda University as its vision is to create Indonesian people to be smart and religious. Believe that spiritual development is vital for growth and essential for dealing with life's problems (Dailey, Robertson, \& Gill, 2015; Dobmeier \& Reiner, 2012). The theory of social competence can be indicated with the adversity quotients as shown in the responsibility of students in finishing the study on time or in 4 year period. It's not only about finishing on time, but it's about the discipline of the students to focus on their study. The condition proves the theory that the behavior of an individual in a given moment, in a real environment, and exerting a given role related to her/his current studies (and the future profession) (José, Grande, Wit, \& Avalos, 2015).

\subsection{Realization of Human Resources (HR)}

Availability of human resources or program implementers is adjusted to the structure of management of the UNIDA BM scholarship program. Data from interviews, observations, and documentation about the objective conditions of $\mathrm{HR}$ responsible for and implementing the program as table 4 . 
Table 4. Human Resources Responsible and Implementing Programs

\begin{tabular}{|c|c|c|c|c|c|}
\hline \multirow{2}{*}{ No. } & & \multirow{2}{*}{ Management Element } & \multicolumn{2}{|c|}{ Objective Condition } & \multirow[t]{2}{*}{ Information } \\
\hline & & & There is & There is no & \\
\hline 1 & Person in charge & Chancellor & $\checkmark$ & & \\
\hline 2 & Executor & Vice Chancellor for Academic Affairs & $\checkmark$ & & \\
\hline 3 & & Deputy Chancellor for Student Affairs & $\checkmark$ & & \\
\hline 4 & & Head of Academic Affairs Bureau & $\checkmark$ & & \\
\hline 5 & & Head of Student Affairs Bureau & $\checkmark$ & & \\
\hline 6 & & Head of the Bureau of Finance & $\checkmark$ & & \\
\hline 7 & & Head of Tahid Bureau of Assessment and & $\checkmark$ & & \\
\hline & & Development (LP2T) & & & \\
\hline 8 & & Head of IT Bureau & $\checkmark$ & & \\
\hline
\end{tabular}

Source: Interviews, Documentation, and Observation

Based on table 3.4, seven elements fulfill the aspects of HR of program implementing. Thus, 100\% of the human resources for implementing the scholarship program are $\mathrm{BM}$ ful filled.

Lecturers are another element that is a factor supporting the implementation of the BM scholarship program. Administratively the number of lecturers in the study program who are implementing the learning process for students of scholarship participants is BM adequate. This can be seen from the ratio of lecturers and students in accordance with applicable laws and regulations. Table 3.5 states that $100 \%$ of the lecturers in the student study program are adequate.

Table 5. Condition of Lecturer Objectives in Program Participant Student Study Program

\begin{tabular}{clc}
\hline & Study program & \multicolumn{2}{c}{ Lecturer Availability } \\
\cline { 3 - 3 } No. & & Adequate \\
\hline 1 & Agribusiness & $\checkmark$ \\
2 & Agrotechnology & $\checkmark$ \\
3 & Fishery & $\checkmark$ \\
4 & Ranch & $\checkmark$ \\
5 & Food and Nutrition Technology & $\checkmark$ \\
6 & Agricultural Industrial Technology & $\checkmark$ \\
7 & Accounting & $\checkmark$ \\
8 & Management & $\checkmark$ \\
9 & Legal studies & $\checkmark$ \\
10 & Public Administration & $\checkmark$ \\
11 & Communication Studies & $\checkmark$ \\
12 & Primary Teacher Education & $\checkmark$ \\
\hline
\end{tabular}

Source: Interview, Observation, and Documentation

Human resources both on the program manager side and lecturers at UNIDA meet the standards according to the BM scholarship guidelines and the needs of lecturers in each study program. The suitability of human resources makes universities as organizers of BM programs assist the government in raising the Development Human Index. The Human Development Index (commonly abbreviated as HDI) is a summary of human development throughout the world and implies whether a country is developed, still developing, or underdeveloped based on factors such as life expectancy, education, literacy, per capita gross domestic product (UNDP, 2016 ) One indicator of the Human Development Index (HDI) is education. Education can be one solution to reduce poverty and unemployment, which automatically develops HDI levels. Education is always related to knowledge where the level of knowledge is measured by the average year of education among the adult population, which is the number average years of education received throughout life by people aged 25 years over and access to learning and knowledge based on the school year expected for school-age children, which is the total number of school years that can be accepted by children entering school if the pattern of age-specific enrollment rates that apply 
remains the same throughout child life (UNDP), 2016.

Lecturer career development is very important for the continuity of education (R R Aliyyah, Lutfah, \& Lathifah, 2017). The ability of the lecturer is the initial foundation in reflecting obligations, duties and responsibilities as a guide in developing the interests, talents and potential of students to be strong and capable of being competitive in facing the challenges of the times in the era of globalization (R R Aliyyah, Widyasari, Mulyadi, Ikhwan, \& Prananosa, 2019).

The outcome of BM is a booster in improving the productivity and competitiveness of Indonesian human resources. The upgrading happens because the government through the University provides special coaching programs to enhance intellectual, spiritual and emotional abilities well when they are in college (Rusi Rusmiati Aliyyah, Rosyidi, \& Yazid, 2019). Thus, the role of the university in providing a style of campus culture can be seen in the implementation of the BM scholarship program.

\section{CONCLUSION}

This research concluded that the giving of BM scholarship to outstanding low-income students provides a solution to accelerate the development of education in Indonesia and give significant impacts on the increasing level of Human Development Index. It also determines that higher education can have a function as an agent of change in the development of students competencies and characters. The higher educations can also have a role as an equal partner of the government in spreading the knowledge and skills.

\section{ACKNOWLEDGEMENTS}

The researcher would like to thank The Ministry of Research, Technology and Higher Education of Republic Indonesia for providing fund in financing the University fees through scholarship.

\section{REFERENCES}

Aliyyah, R. R., Lutfah, S. A., \& Lathifah, Z. K. (2017). The Management of Teachers At Elementary Schools. Didaktika Tauhidi, 4(2), 75-86.
Study of an Education Scholarship Program (BidikMisi) for Students in Indonesia. Journal of Physics: Conference Series, 1175, 1-7. https://doi.org/10.1088/1742-6596/1175/1/012171

Aliyyah, R. R., Widyasari, Mulyadi, D., Ikhwan, S., \& Prananosa, A. G. (2019). Students' Management At Elementary School. Didaktika Tauhidi, 6(April). https://doi.org/10.30997/dt.v6i1.1355

Baffoe, G. (2019). Exploring the utility of Analytic Hierarchy Process (AHP) in ranking livelihood activities for effective and sustainable rural development interventions in developing countries. Evaluation and Program Planning, 72(October 2018), 197-204. https://doi.org/10.1016/j.evalprogplan.2018.10.017

Bank, W. Share of Population Below National Poerty Line (2017).

Benavot, A. (2016a). Assuring quality education and learning: Lessons from Education for All. PROSPECTS. https://doi.org/10.1007/s11125-016-9386-1

Benavot, A. (2016b). Assuring quality education and learning: Lessons from Education for All. Prospects, 46(1), 5-14. https://doi.org/10.1007/s11125-016-9386-1

Bilbao-ubillos, J. (2013). Another Approach to Measuring Human Development: The Composite Dynamic Human Development Index, 473-484. https://doi.org/10.1007/s11205-012-0015-y

Biro Pusat Statistik. (2016). Jumlah penduduk miskin per provinsi. Jakarta: bps.go.id.

Caroline, P., \& Miranda, M. De. (2014). Human Development Index Based on ELECTRE TRI-C Multicriteria Method: An Application in the City of Recife. https://doi.org/10.1007/s11205-014-0836-y

Chaaban, J., Irani, A., \& Khoury, A. (2015). The Composite Global Well-Being Index ( CGWBI ): A New Multi-Dimensional Measure of Human. Social Indicators Research. https://doi.org/10.1007/s11205-015-1112-5

Creswell, J. C. (2012). Educational Reserach; Planning, Conducting and Evaluating Quantitative and Qualitative Research.

Dailey, S. F., Robertson, L. A., \& Gill, C. S. (2015). Spiritual Competency Scale: Further Analysis. Measurement and Evaluation in Counseling and Develpoment. https://doi.org/10.1177/0748175614544688

Dobmeier, R. A., \& Reiner, S. M. (2012). Spirituality in the Counselor Education Curriculum: A National Survey of Student Perceptions, 57(April), 47-65.

Doganay, A., \& Ozturk, A. (2017). Developing Attitudes towards Human Rights through Socioscientific Issuesin Science Courses: An Action Research. Remie-Multidisciplinary Journal of Educational Research, 7(3), 253-286. https://doi.org/10.17583/remie.2017.2873

Franz, N. (2016). A Holistic Model of Engaged Scholarship: Telling the Story across Higher Education's Missions, 20(1), 197-216. 
migration: Global challenges and opportunities for lifelong learning. International Review of Education, 60(4), 481-497. https://doi.org/10.1007/s11159-014-9441-1

Hancock, Dawson R and Alozzine, B. (2006). Doing Case Study. New Yok: Teachers College Press.

Hannum, E., Liu, R., Alvarado-urbina, A., \& Hannum, E. (2017). Evolving approaches to the study of childhood poverty and education education. Comparative Education, 53(1), 1-31. https://doi.org/10.1080/03050068.2017.1254955

Hitchcock, L. I., Peterson, D. T., Debiasi, L., Varley, A., White, M. L., Iverson, L., ... White, M. L. (2018). Learning About Poverty Through Simulation: A Pilot Evaluation Learning About Poverty Through Simulation: A Pilot Evaluation. Journal of Social Work Education, 54(3), 517-531. https://doi.org/10.1080/10437797.2018.1434427

Huberman, M. B. M. and A. M. (1992). Analisis Data Kualitatif: Buku Sumber Tentang Metode-Metode Baru. Jakarta: UI.

Husni, N. M. Al, \& Rouadi, N. El. (2016). Interdisciplinary Curriculum Empowers Cognitive Advancement to Solve Real Life Problems, 5(4), 34-43. https://doi.org/10.5539/jel.v5n4p34

Irabor, Q. O. (2018). Educational policies and programmes implementations : A case study of education funding, universal basic education ( UBE ) and teacher education. International Journal of Administration and Policy Studies, 10(August), 91-102. https://doi.org/10.5897/IJEAPS2016.0457

Jenderal, D., Dan, P., Riset, K., Dan, T., \& Tinggi, P. (2016). Bantuan Biaya Pendidikan Bidikmisi Tahun 2016.

José, F., Grande, S., Wit, H. J., \& Avalos, J. B. (2015). Evaluation Of Social Competencies In Chemical Engineering:Application and Results of The Pilot Test ( Academic Year 2012-2013). Journal of Technology and Science Education, 5(1993), 141-150.

Kemendikbud. (2014a). Peraturan Menteri Pendidikan dan Kebudayaan Nomor 96 Tahun 2014 tentang Penyelenggaraan Bantuan Biaya Pendidikan Bidikmisi. Jakarta: Kemendikbud.

Kemendikbud. (2014b). Peraturan Menteri Pendidikan dan Kebudayaan RI Nomor 96 Tahun 2014 Tentang Penyelenggaraan Bantuan Biaya Bidikmisi.

Lourenc, R. (2017). A Multicriteria Approach to the Human Development Index Classification. https://doi.org/10.1007/s11205-017-1556-x

Madani, R. A. (2019). Analysis of Educational Quality , a Goal of Education for All Policy. Higher Education Studies, 9(1), 100-109. https://doi.org/10.5539/hes.v9n1p100

Mawer, M. (2017). Approaches to Analyzing the Outcomes of International Scholarship Programs for Higher Education. Journal of Studies in International Education, 20-24. https://doi.org/10.1177/1028315316687009

Miles, Mathew B, Hubermen, Michael, Saldana, J. (2014). Qualitative Data Analysis. Book (2nd ed.). Sage Publishing.
Miles B Matthew, Hubbermean A Michael, Saldana, J. (2014). Qualitative Data Analysis, A Method Sourcebook.

Mwangi, C. A. G. (2018). Education Partnerships through a Mutuality Lens Partner Positioning: Examining International Higher Education Partnerships through a Mutuality Lens. The Review of Higher Education, 41(1), 33-60.

Peklaj, C. (2015). Teacher Competencies through the Prism of Educational Research Učiteljeve kompetence skozi prizmo raziskav v izobraževanju. C.E.P.S Journal, 5, 183-204.

Redding, S. (2015). Why the Personal Competencies Matter by. Center on Innovations in Learning.

Ristekdikti. (2015). Ristekdikti. Jakarta: Ristekdikti.

Sekneg. (2012). Undang-Undang RI No 12 Tahun 2012 tentang Pendidikan Tinggi. Jakarta: Sekneg.

Shaposhnykova, I., \& Shaposhnykov, K. (2018). Socio-Economic Features of the Development of Human Capital ( on the Example of Professional Identity of Students of Border Areas ). Espacios, 39(52), 4.

Surr,Wendy. Redding, S. (2017). Staying Shallow or Going Deep? Center on Innovations in Learning, (May).

Tierney, B. W. G., Sallee, M. W., \& Venegas, K. M. (2016). Access and Financial Aid: How American-Indian Students Pay for College. Journal of College Admission, 2(4), 11.

UNDP. (2016). Human Development Report 2016. UNDP.

Villalobos, C., Treviño, E., Wyman, I., \& Scheele, J. (2017). Social justice debate and college access in Latin America: merit or need? The role of educational institutions and states in broadening access to higher education in the region. Education $\begin{array}{llll}\text { Policy Analysis } & \text { 25(0), } & \end{array}$ https://doi.org/10.14507/epaa.25.2879

Williams, M. R., \& Nourie-manuele, M. (2018). The Role of the Community College in Addressing Poverty, (184), 17-26. https://doi.org/10.1002/cc.20324

Younus, F., Farooq, R. A., Tabassum, R., \& Scholar, P. D. (2017). Weaknesses in Evaluation of Teaching Practice in the Formal and Non-Formal Teacher Education Institutions. Journal Of Educational Research, 20(2), 159-173. 